\title{
HUBUNGAN DOMINANSI POHON DENGAN TEMPERATURE HUMIDITY INDEX (THI) DI HUTAN KOTA BABAKAN SILIWANGI BANDUNG JAWA BARAT
}

Relationship of Dominance of Tree with Temperature Humidity Index in Babakan Siliwangi Forest Urban, Bandung West Java

\author{
Muhammad Elvan Nurfajri ${ }^{1)}$, Raizal Fahmi Solihat ${ }^{2)}$, Ika Nofi Hastuti ${ }^{3)}$ \\ 1) Mahasiswa Fakultas Kehutanan Universitas Winaya Mukti, Sumedang \\ ${ }^{2)}$ Pengajar di Fakultas Kehutanan Universitas Winaya Mukti, \\ 3) Pengajar di Fakultas Kehutanan Universitas Winaya Mukti \\ J1 Raya Bandung-Sumedang km 29 Tanjungsari, Sumedang 45362
}

\section{Diterima 15 September 2018/Disetujui 10 Oktober 2018}

\begin{abstract}
Physical development in the city of Bandung which is increasing causes a decrease in green open space. Babakan Siliwangi Bandung City Forest is one of the green open spaces so it is necessary to know the correlation between tree dominance and the Temperature Humidity Index (THI) value in the formation of micro climates. The object research is to determine the relationship between tree dominance and THI. The method by vegetation analysed, measuring temperature and humidity. The results of research are: 1) Comfort index (THI) in the Babakan Siliwangi City Forest Park in Bandung in August 2017 is relatively comfortable $<26$ THI. 2) The correlation value of tree dominance with THI is -0.14 which means that there is no relationship between the dominance value and THI.
\end{abstract}

Keywords : Tree, Forest urban, THI, Bandung

\section{PENDAHULUAN}

Pembangunan fisik di Kota Bandung yang semakin meningkat menyebabkan menurunnya ruang terbuka hijau. Berdasarkan UU Nomor 26 Tahun 2007 Tentang Penataan Ruang, proporsi ruang terbuka hijau pada wilayah kota paling sedikit 30 (tiga puluh) persen dari luas wilayah kota. Pembangunan fisik seperti permukiman penduduk, perkantoran, pusat perbelanjaan di perkotaan 
sejatinya ditujukan untuk memberikan kemudahan bagi manusia dalam menjalani hidup. Namun dengan semakin meningkatnya pembangunan tersebut, keberadaan ruang terbuka hijau $(\mathrm{RTH})$ atau ruang-ruang kosong yang ditumbuhi pepohonan menjadi berkurang dan berpengaruh pada ketidak seimbangan ekosistem.

Zoer'aini (2005) mengemukakan bahwa hutan kota memiliki fungsi lansekap (fungsi fisik dan sosial), fungsi ekologi dan fungsi estetika. Fungsi fisik yaitu vegetasi di dalamnya sebagai perlindungan kondisi fisik alami seperti angin, sinar matahari, pemandangan yang kurang bagus dan bau. Vegetasi berfungsi sebagai pelengkap, pemersatu, penegas, pengenal, pelembut dan pembingkai. Fungsi sosial adalah penataan vegetasi dalam hutan kota yang baik akan memberikan tempat interaksi sosial yang sangat produktif misalnya untuk rekreasi, olahraga dan sebagai tempat interaksi sosial lainnya.

Penyelenggaraan RTH di perkotaan sangat penting karena memiliki fungsi ekologis, sosial budaya, ekonomi dan estetika. Ahmad et al (2012) berpendapat bahwa RTH berperan sebagai pengatur iklim mikro dapat menurunkan suhu permukaan yang secara langsung berpengaruh terhadap sebaran suhu udara dan dapat meningkatkan kenyamanan hidup masyarakat. Berdasarkan keterangan tersebut, perlu dilakukan penelitian pada Hutan Kota Babakan Siliwangi Bandung untuk mengetahui adanya kolerasi antara dominansi pohon dengan nilai Temperature Humidity Index (THI) dalam pembentukan iklim mikro.

\section{METODE PENELITIAN}

\section{Tempat dan Waktu Penelitian}

Penelitian dilaksanakan pada bulan Juli - Agustus 2017. Lokasi penelitian berada di Hutan Kota Babakan Siliwangi Kota Bandung Provinsi Jawa Barat dengan luas areal sekitar $\pm 3.68 \mathrm{Ha}$

\section{Pengumpulan Data Nilai THI}

\section{a. Penentuan Plot Pengamatan}

Berdasarkan penelitian sebelumnya penelitian ini dirancang dengan menggunakan metode grid (pemetakan) Rohman et al. (2012) . Lokasi penelitian di petak-petak dengan ukuran 40 meter x 40 meter, sehingga didapatkan petak pengamatan sebanyak 23 plot dari hasil luasan Hutan Kota Babakan Siliwangi dibagi dengan luasan petak plot yaitu $: \underline{3,6 \mathrm{Ha}}=22,5=23$ Plot

\section{b. Pengumpulan Data Suhu dan Kelembaban}

Metode grid akan digunakan dalam pengambilan data suhu, kelembaban dan vegetasi pohon untuk menentukan tingkat kenyamanan. Titik pengambilan data suhu dan kelembaban udara berada di tengah grid dengan jarak 20 meter ke kiri 
dan 20 meter ke kanan. Pengambilan data dilakukan pada pagi (06.00-07.00), siang (12.00-13.00), sore (18.00-19.00). Pengambilan data suhu, kelembaban dan vegetasi pohon dilakukan dua hari sekali selama bulan Agustus 2017.

Data suhu dan kelembaban yang diukur pada masing masing petak akan digunakan untuk menghitung Temperature Humidity Index (THI), Nieuwolt (1975) dalam Effendy dan Aprihatmoko (2014) dengan rumus sebagai berikut yaitu:

$\mathrm{THI}=0,8 \mathrm{~T}+(\mathrm{RH} x \mathrm{~T}) / 500$

$\mathrm{T} \quad=$ suhu atau temparatur udara $\left({ }^{\circ} \mathrm{C}\right)$

$\mathrm{RH} \quad=$ Kelembaban udara $(\%)$

Berdasarkan data suhu dan kelembaban yang diukur pada masing-masing titik pengamatan akan didapat nilai iklim masing-masing titik, apabila iklim semua titik di rata-rata maka nilai rata-rata iklim tersebut adalah nilai iklim Hutan Kota Babakan Siliwangi.

Hasil pengukuran data suhu dan kelembaban udara selanjutnya dirata-rata dan dihitung nilai Temperature Humidity Index (THI) untuk menunjukkan kenyamanan suatu lokasi dengan persamaan Nieuwolt (1975) dalam Effendy dan Aprihatmoko (2014) yaitu:

$\mathrm{THI}=0,8 \mathrm{~T}+(\mathrm{RHxT} / 500)$

Keterangan:

$\mathrm{T}=$ Suhu udara $\left({ }^{\circ} \mathrm{C}\right)$

RH $=$ Kelembaban udara $(\%)$

Suhu udara dan kelembaban udara akan menentukan kenyamanan. Rentang nilai indeks kenyamanan didapat dari persamaan Nieuwolt yang dihasilkan oleh penilaian responden dengan rentang nilai sebagai berikut:

a. Indeks $21<$ THI $<24$ Nyaman.

b. Indeks $25<\mathrm{THI}<26$ Sedang.

c. Indeks THI $>26$ Tidak nyaman.

Nilai THI untuk menentukan kenyamanan manusia diperoleh berdasarkan fisiologi manusia yang berhubungan dengan kondisi lingkungan sekitarnya.

\section{c. Pengumpulan Data Vegetasi Pohon}

Pengambilan data vegetasi pada Hutan kota Babakan Siliwangi dilakukan pada masing-masing petak. Data vegetasi pohon dilakukan dengan metode sensus pada semua petak plot dengan cara perhitungan terhadap parameter kuantitatif vegetasi sebagai berikut :

a. Kerapatan $(\mathrm{K})(\mathrm{ind} / \mathrm{ha})=\underline{\text { Jumlah Individu Suatu Jenis }}$

Total Luas Plot Contoh 
b. Frekuensi $(\mathrm{F})=\underline{\text { Jumlah jenis (i) yang ditemukan di lokasi penelitian }}$ Jumlah Plot Contoh

c. Dominansi (D) ) $\left(\mathrm{m}^{2} / \mathrm{ha}\right)=\underline{\text { Luas bidang dasar suatu jenis }}$ Total Luas Plot Contoh

\section{d. Korelasi antara THI dengan Dominansi Pohon}

Nilai korelasi antara THI dengan dominansi pohon didapat dari Koefisien Korelasi berdasarkan rumus korelasi dibawah ini :

$\mathrm{r}=\frac{\mathrm{n} \Sigma \mathrm{xy}-(\Sigma \mathrm{x})(\Sigma \mathrm{y})}{\sqrt{ }\left\{\mathrm{n} \Sigma \mathrm{x}^{2}-(\Sigma \mathrm{x})^{2}\right\}\left\{\mathrm{n} \Sigma \mathrm{y}^{2}-(\Sigma \mathrm{y})^{2}\right\}}$

\section{HASIL DAN PEMBAHASAN}

\section{Kondisi Lokasi Penelitian}

\section{Demografi}

Secara geografis Taman Hutan Kota Babakan Siliwangi Bandung terletak pada LS $7^{\circ} 6^{\circ} 55^{\prime}$ ' dan $107^{\circ} 36^{\circ} 36^{\prime \prime}$ BT. Secara administrasi Taman Hutan Kota Babakan Siliwangi berada pada Kecamatan Coblong dan Kelurahan Lebak Siliwangi. Luas wilayah Kecamatan Coblong adalah 743.3 Ha dan kelurahan Lebak Siliwangi memiliki luas $100 \mathrm{Ha}$.

\section{Iklim}

Iklim kecamatan Coblong identik dengan iklim Kota Bandung, yang dipengaruhi oleh pegunungan di sekitarnya sehingga cuaca yang terbentuk sejuk dan lembab. Temperatur rata-rata selama tiga tahun yaitu 23,50 dan mencapai suhu tertinggi pada Bulan Septemberl yaitu 30,010C. Sementara untuk curah hujan di Kota Bandung masih cukup tinggi, yaitu rata-rata $223.45 \mathrm{~mm}$ dengan jumlah hari hujan sebanyak 226 hari selama tahun 2014.

\section{Indeks Kenyamanan Taman Hutan Kota Babakan Siliwangi Bandung berdasarkan Temperature Humidity Index (THI)}

Berdasarkan pengamatan yang dilakukan di lapangan selama satu bulan pada bulan Agustus 2017, dengan parameter iklim yang diamati yaitu suhu dan kelembaban untuk menghitung indeks kenyamanan (THI) Taman Hutan Kota Babakan Siliwangi Bandung diperoleh data seperti yang terlihat pada Tabel 1. 
Berdasarkan Tabel 1 dapat dilihat bahwa pada bulan Agustus 2017 THI Taman Hutan Kota Babakan Siliwangi Bandung masuk dalam kategori nyaman, ini ditunjukkan dengan nilai THI rata-rata bulanan Taman Hutan Kota Babakan Siliwangi Bandung yaitu 22.81. Suhu udara rata-rata bulanan pada Taman Hutan Kota Babakan Siliwangi Bandung untuk bulan Agustus 2017 yaitu $25.36^{\circ} \mathrm{C}$, sedangkan untuk kelembaban udara rata-rata bulanannya yaitu $59.29 \%$.

Nilai THI rata-rata di Taman Hutan Kota Babakan Siliwangi Bandung pada bulan Agustus 2017 secara keseluruhan masuk dalam kondisi nyaman, dimana nilai THI paling besar tercatat pada tanggal 15 dan 17 Agustus dengan nilai THI yaitu 25,69 dan 25.10. Tanggal 15 Agustus tercatat suhu udara tertinggi yaitu $27,91^{\circ} \mathrm{C}$ dengan kelembaban udara 59,30\%, dan pada tanggal 17 Agustus suhu udara yang tercatat yaitu $27,36^{\circ} \mathrm{C}$ dengan kelembaban udara $58,92 \%$.

Tabel 1. Hasil Pengamatan THI Taman Hutan Kota Babakan Siliwangi Bandung

\begin{tabular}{rlll}
\hline Tanggal & \multicolumn{1}{c}{ T $\left({ }^{\circ} \mathbf{C}\right)$} & \multicolumn{1}{c}{$\mathbf{R H}(\boldsymbol{\%})$} & \multicolumn{1}{c}{ THI } \\
\hline Tgl 01/08/2017 & 25.7 & 60.26 & 23.65 \\
Tgl 03/08/2017 & 25.41 & 59.71 & 23.35 \\
Tgl 05/08/2017 & 24.98 & 59.17 & 22.93 \\
Tgl 07/08/2017 & 24.24 & 58.88 & 22.23 \\
Tgl 09/08/2017 & 24.33 & 59.17 & 22.32 \\
Tgl 11/08/2017 & 25.31 & 59.4 & 23.24 \\
Tgl 13/08/2017 & 24.91 & 59.36 & 22.87 \\
Tgl 15/08/2017 & 27.92 & 59.3 & 25.69 \\
Tgl 17/08/2017 & 27.36 & 58.92 & 25.10 \\
Tgl 19/08/2017 & 24.80 & 59.10 & 22.77 \\
Tgl 21/08/2017 & 24.933 & 58.78 & 22.87 \\
Tgl 23/08/2017 & 23.7 & 59.08 & 21.76 \\
Tgl 25/08/2017 & 24.74 & 59.49 & 22.73 \\
Tgl 27/08/2017 & 25.13 & 59.21 & 23 \\
Tgl 29/08/2017 & 26.99 & 59.59 & 25.06 \\
Rata rata & 25.364 & 59.29 & 22.81 \\
\hline
\end{tabular}

Nilai THI Taman Hutan Kota Babakan Siliwangi Bandung yang paling kecil terjadi pada tanggal 07 dan 23 Agustus 2017 dengan nilai THI berturut-turut yaitu 22,23 dan 21,76. Suhu udara terendah juga terjadi pada tanggal 07 dan 23 Agustus 2017 yaitu $24,24^{\circ} \mathrm{C}$ dan $23,7^{\circ} \mathrm{C}$. Data tanggal 07 dan 23 Agustus baik dari data suhu dan nilai THI yang lebih kecil menyebabkan terjadinya fluktuasi (Gambar 1). 


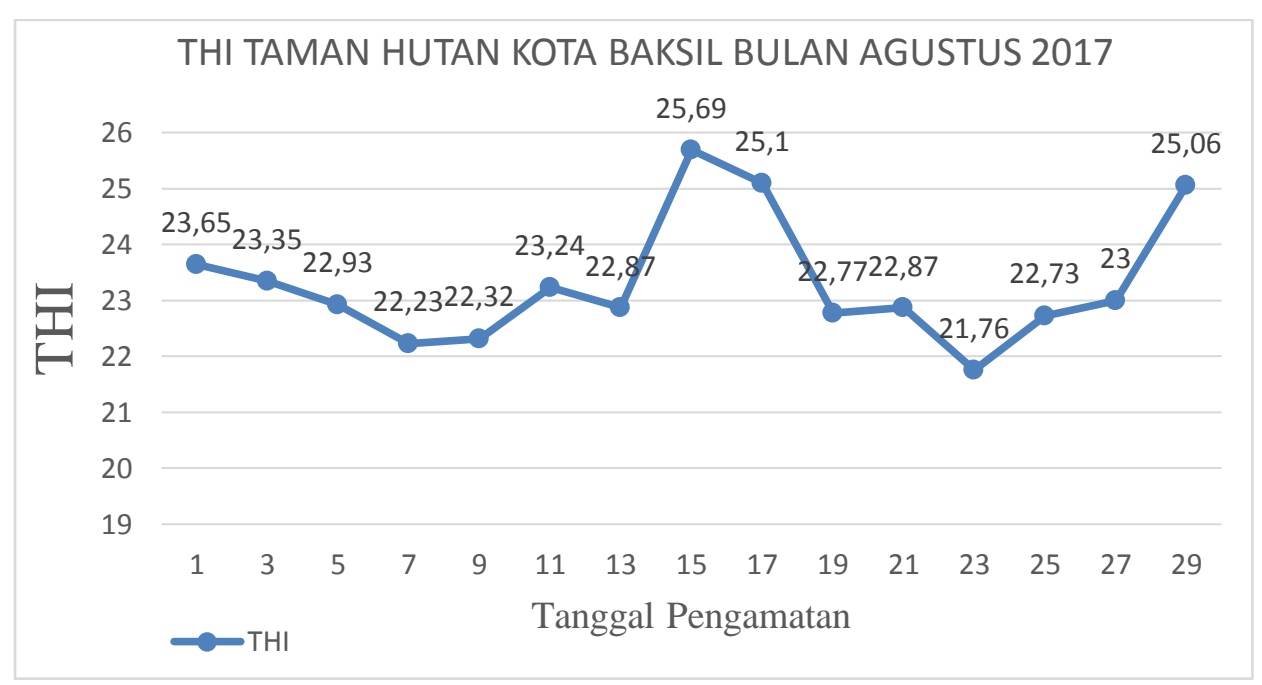

Sumber : Hasil Penelitian 2017

Gambar 1. Rata rata nilai THI Taman Hutan Kota Babakan Siliwangi Bulan Agustus 2017

Berdasarkan data grafik diatas maka didapatkan rata rata nilai THI Taman Hutan Kota Babakan Siliwangi Bulan Agustus sebesar 23,30 dan nilai tersebut memasuki kategori nyaman. dapat disimpulkan bahwa indeks kenyamanan (THI) Taman Hutan Kota Babakan Siliwangi Bandung bulan Agustus 2017 masuk dalam kondisi nyaman.

Faktor utama yang mempengaruhi hasil perhitungan THI adalah suhu udara, jadi fluktuasi yang terjadi pada tanggal 07 dan 23 Agustus (Grafik 2) disebabkan oleh suhu udara rendah sehingga nilai THI menjadi lebih kecil. Apabila dilihat kondisi di lapangan pada tanggal 07 dan 23 Agustus kondisi langit pada saat pengamatan (pagi, siang dan sore) cerah, sedangkan pada siang hari kondisi langit berawan yang menghalangi radiasai matahari, selain itu juga kondisi angin di lapangan cukup kencang terutama pada siang hari. Berdasarkan kondisi tersebut dapat disebutkan bahwa faktor yang mempengaruhi THI adalah kondisi awan di langit dan angin di lokasi penelitian. Hal ini sesuai dengan pendapat Lakitan (2002) yang menyatakan bahwa angin mempunyai fungsi yang sangat penting yaitu dalam mencampur lapisan udara, antara udara panas dengan udara dingin, antara udara lembab dengan udara kering, antara udara yang kaya karbon dioksida dengan udara yang kandungan karbon dioksida lebih rendah. Sedangkan faktor awan didukung oleh pendapat Adipedia (2011) menyatakan jika suatu daerah terjadi awan (mendung) maka panas yang diterima bumi relatif sedikit, hal ini disebabkan sinar matahari tertutup oleh awan dan kemampuan awan menyerap panas matahari. Permukaan daratan lebih cepat menerima panas dan cepat pula melepaskan panas. Apabila 
udara pada siang hari diselimuti oleh awan, maka temperatur udara pada malam hari akan semakin dingin.

\section{Indeks Kenyamanan THI Masing-masing Petak Pengamatan}

Hasil pengamatan THI pada masing-masing petak pengamatan rata-rata bulan Agustus, dapat dilihat pada Grafik 2.

Berdasarkan Grafik 2 dapat diketahui bahwa nilai THI rata-rata pada semua petak pengamatan masuk dalam kondisi nyaman. Nilai THI paling kecil terdapat pada petak $22(22,85)$, sedangkan nilai THI yang paling tinggi terdapat pada petak 12 dan $19(23,86)$.

Nilai THI masing-masing petak tidak hanya dipengaruhi oleh nilai dominansi pohon, akan tetapi faktor letak titik pengamatan juga berpengaruh, artinya titik pengamatan ada di bawah kanopi pohon atau tidak (terkena radiasi matahari langsung). Secara garis besar apabila dilihat pada Grafik 2 dapat dikatakan bahwa nilai THI pada petak yang memiliki nilai dominansi pohon, itu lebih kecil nilainya apabila dibandingkan dengan nilai THI pada petak yang tidak memiliki dominansi pohon sama sekali. Seperti pada petak 12 dan 13 yang mana memiliki dominansi yang sangat kecil (0,00042 dan 0,00036). Akan tetapi tidak selalu nilai dominansi yang besar akan menghasilkan nilai THI yang kecil (nyaman), hal ini tergantung pada letak titik pengamatan tersebut apakah tertutupi oleh kanopi pohon atau tidak. Tutupan kanopi pohon diindikasikan mempengaruhi nilai indeks kenyamanan petak pengamatan.

Kehadiran tanaman dalam RTH membuat lingkungan hidup terasa lebih nyaman, karena disamping memperindah lingkungan, tanaman juga dapat memodifikasi unsur-unsur iklim. Tanaman memang tidak mengubah unsur-unsur iklim tersebut secara drastis, tetapi perubahan kecil yang ditimbulkan sangat terasa sekali bagi manusia. Sebagai contoh adalah kondisi udara di bawah pohon yang rindang pada saat matahari bersinar penuh. Udara di bawah pohon tersebut akan terasa lebih teduh, sejuk, dan lembab. Lebih teduh karena intensitas cahaya matahari langsung sebagian besar tidak dapat menembus kanopi pohon tersebut. Lebih sejuk karena berkurangnya masukan energi cahaya untuk memanaskan udara di bawah permukaan kanopi (Lakitan, 2002). 


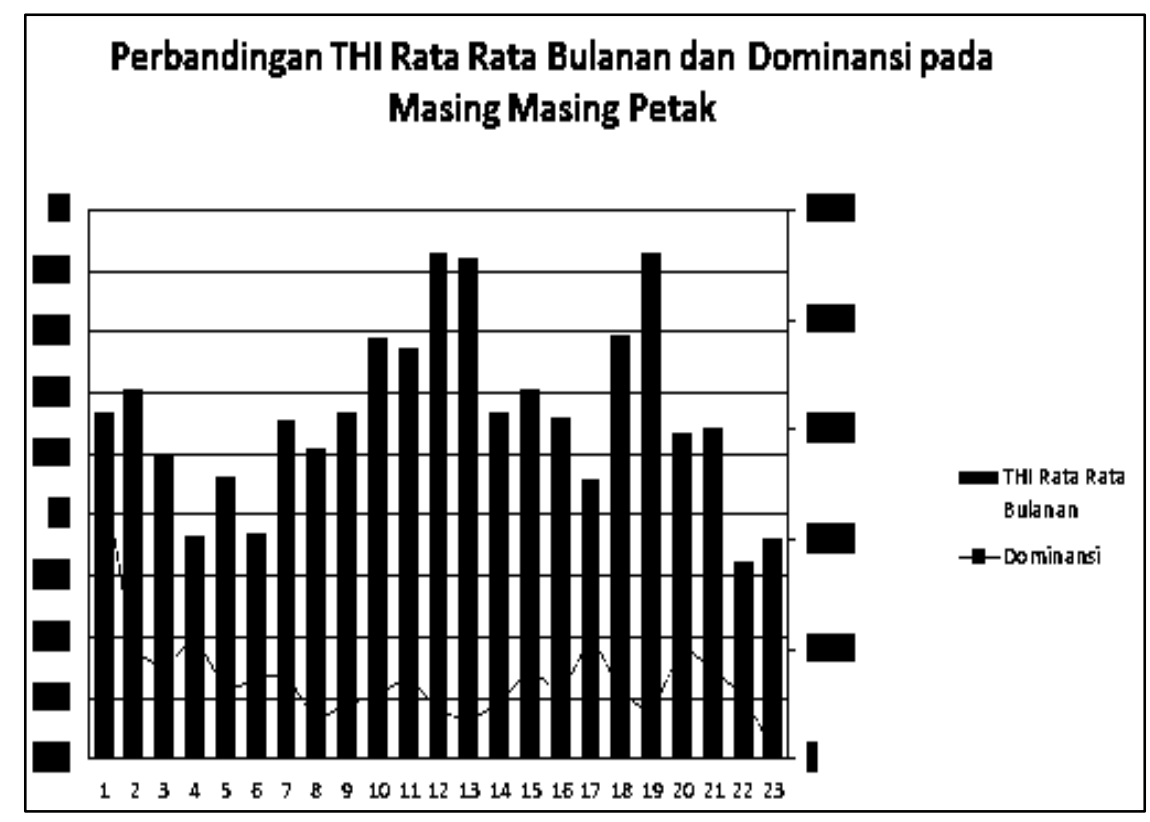

Sumber : Hasil Penelitian 2017

Grafik 2. Nilai THI Masing-masing Petak Pengamatan

\section{Analisis Vegetasi}

Keberadaan vegetasi dalam RTH membuat lingkungan hidup terasa lebih nyaman, karena disamping memperindah lingkungan, tanaman juga dapat memodifikasi unsur-unsur iklim. Tanaman memang tidak mengubah unsur-unsur iklim tersebut secara drastis, tetapi perubahan kecil yang ditimbulkan sangat terasa bagi manusia. Lebih sejuk karena berkurangnya masukan energi cahaya untuk memanaskan udara di bawah permukaan kanopi (Lakitan 2002). Hasil pengamatan analisis vegetasi meliputi frekuensi, kerapatan dan dominansi dapat dilihat pada Tabel 2 .

Berdasarkan hasil analisis vegetasi (Tabel 2) nilai dominansi yang paling besar terdapat pada pohon Kaliandra (0.00018), dan nilai dominansi yang paling kecil terdapat pada pohon Tanjung (0.00004).

Nilai korelasi dominansi pohon dengan THI adalah -0,14 yang berarti antara nilai dominansi dengan THI tidak ada hubungan. Namun demikian apabila dilihat nilai THI disetiap petak pada Grafik 2 dapat disimpulkan bahwa nilai THI pada petak yang memiliki nilai dominansi pohon, itu lebih kecil nilainya apabila dibandingkan dengan nilai THI pada petak yang tidak memiliki dominansi pohon sama sekali. Akan tetapi tidak selalu nilai dominansi yang besar akan menghasilkan nilai THI yang kecil (nyaman), hal ini tergantung pada letak titik pengamatan tersebut apakah tertutupi oleh kanopi pohon atau tidak. Tutupan kanopi pohon diindikasikan mempengaruhi nilai indeks kenyamanan petak pengamatan. 
Tabel 2. Data Hasil analisis vegetasi di Taman Hutan Kota Babakan Siliwangi Bandung

\begin{tabular}{|c|c|c|c|c|c|c|c|}
\hline No & $\begin{array}{l}\text { Nama } \\
\text { Lokal }\end{array}$ & Nama Ilmiah & $\begin{array}{l}\text { Jumlah } \\
\text { Individu }\end{array}$ & $\begin{array}{c}\text { Jumlah } \\
\text { plot } \\
\text { ditemukan }\end{array}$ & $\mathbf{F}$ & $\mathbf{K}$ & D \\
\hline 1 & Beringin & Ficus benjamina & 8 & 4 & 0.1739 & 0.3478 & 0.00011 \\
\hline 2 & Biola cantik & $\begin{array}{l}\text { ficus lyrata } \\
\text { Ptersopenmum }\end{array}$ & 10 & 5 & 0.2174 & 0.4348 & 0.00006 \\
\hline 3 & Cerelang & dipersifolium & 8 & 4 & 0.1739 & 0.3478 & 0.00006 \\
\hline 4 & Congkok & Curculigo capitulate & 15 & 6 & 0.2609 & 0.6522 & 0.00008 \\
\hline 5 & Damar & Agathis damara & 16 & 7 & 0.3043 & 0.6957 & 0.00015 \\
\hline 6 & Flamboyan & Delonix regia & 10 & 5 & 0.2174 & 0.4348 & 0.00010 \\
\hline 7 & Jati & $\begin{array}{l}\text { Tectona grandis } \\
\text { Caliandra }\end{array}$ & 13 & 5 & 0.2174 & 0.5652 & 0.00008 \\
\hline 8 & Kaliandra & $\begin{array}{l}\text { Callothyrsus } \\
\text { Cinnamoтum }\end{array}$ & 21 & 6 & 0.2609 & 0.9130 & 0.00018 \\
\hline 9 & Kayu Manis & burmanii & 10 & 6 & 0.2609 & 0.4348 & 0.00006 \\
\hline 10 & Kenari & Aleurites Moluccana & 10 & 7 & 0.3043 & 0.4348 & 0.00007 \\
\hline 11 & Ketapang & Terminalia Catappa & 11 & 4 & 0.1739 & 0.4783 & 0.00008 \\
\hline 12 & Ki Beusi & Englehardia Spicata & 11 & 5 & 0.2174 & 0.4783 & 0.00007 \\
\hline 13 & Kola & $\begin{array}{l}\text { Cola nittida } \\
\text { Swetenia }\end{array}$ & 8 & 4 & 0.1739 & 0.3478 & 0.00005 \\
\hline 14 & Mahoni & Macrophylla & 10 & 5 & 0.2174 & 0.4348 & 0.00010 \\
\hline 15 & Mangga & $\begin{array}{l}\text { Mangifera indica } \\
\text { Artocarpus }\end{array}$ & 11 & 6 & 0.2609 & 0.4783 & 0.00005 \\
\hline 16 & Nangka & heterophyllus & 6 & 3 & 0.1304 & 0.2609 & 0.00005 \\
\hline 17 & Pinus & $\begin{array}{l}\text { Pinus merkusii } \\
\text { Syzygium }\end{array}$ & 11 & 5 & 0.2174 & 0.4783 & 0.00010 \\
\hline 18 & Salam & polyanthum & 12 & 4 & 0.1739 & 0.5217 & 0.00009 \\
\hline 19 & Sempur & Dilenia indica & 22 & 8 & 0.3478 & 0.9565 & 0.00017 \\
\hline 20 & Sukun & Artocarpus altilis & 9 & 4 & 0.1739 & 0.3913 & 0.00007 \\
\hline 21 & Tanjung & Mimusops elengi & 5 & 3 & 0.1304 & 0.2174 & 0.00004 \\
\hline 22 & Trembesi & Albizia saman & 14 & 7 & 0.3043 & 0.6087 & 0.00012 \\
\hline \multicolumn{3}{|c|}{ Jumlah } & 251 & 113 & 4.913043 & 10.91304 & 0.001924 \\
\hline
\end{tabular}

Tabel 3. Hubungan THI dengan dominansi pohon

\begin{tabular}{ccc}
\hline Plot & Rata-rata & Nilai \\
\hline
\end{tabular}




\begin{tabular}{ccc}
\hline & THI / Bulan & Dominansi \\
\hline 1 & 23.34 & 0.00255 \\
2 & 23.41 & 0.00099 \\
3 & 23.19 & 0.00082 \\
4 & 22.93 & 0.00114 \\
5 & 23.13 & 0.00061 \\
6 & 22.94 & 0.00074 \\
7 & 23.31 & 0.00078 \\
8 & 23.22 & 0.00036 \\
9 & 23.34 & 0.00051 \\
10 & 23.58 & 0.0006 \\
11 & 23.55 & 0.00075 \\
12 & 23.86 & 0.00042 \\
13 & 23.84 & 0.00036 \\
14 & 23.34 & 0.0005 \\
15 & 23.41 & 0.00082 \\
16 & 23.32 & 0.00059 \\
17 & 23.12 & 0.00114 \\
18 & 23.59 & 0.00063 \\
19 & 23.86 & 0.0004 \\
20 & 23.27 & 0.001 \\
21 & 23.29 & 0.00084 \\
22 & 22.85 & 0.00056 \\
23 & 22.92 & 0.0001 \\
\hline
\end{tabular}

\section{KESIMPULAN}

1. Indeks kenyamanan (THI) yang ada di Taman Hutan Kota Babakan Siliwangi Bandung pada bulan Agustus 2017 tergolong nyaman <26 THI

2. Nilai korelasi dominansi pohon dengan THI adalah $-0,14$ yang berarti antara nilai dominansi dengan THI tidak ada hubungan. 
Adipedia. 2011. Faktor yang Mempengaruhi Perbedaan Suhu Udara (Temperatur) di Berbagai Daerah. Diunduh dari:http://www.adipedia.com/2011/04/faktorfaktor-yang mempengaruhi.html. Diakses Tanggal 15 Juni 2017.

Ahmad F, Arifin H, Dahlan EN, Effendy S. dan Kurniawan R. 2012. Analisis hubungan luas ruang terbuka hijau (rth) dan perubahan suhu di Kota Palu. Jurnal Hutan Tropis.

Effendy S. dan Aprihatmoko F. 2014. Kaitan RTH dengan kenyamanan termal perkotaan. Jurnal Agromet. 28(1) : 23-32.

Lakitan B. 2002. Dasar-Dasar Klimatologi. Buku. PT Raja Grafindo Persada. Jakarta

Rohman H, Komang A. dan I Gusti AG. 2012 Evaluasi Indeks Kenyamanan Taman Kota (Lapangan Puputan Badung I Gusti Ngurah Made Agung) Denpasar, Bali. Program Studi Agroekoteknologi, Fakultas Pertanian, Universitas Udayana.

Zoer'aeni, D. I. 2005. Tantangan Lingkungan dan Lansekap Hutan Kota. Buku. Bumi Aksara. Jakarta. 